Georgia: Partisan Parity in the Peach State

John A. Clark, Audrey A. Haynes, Brad Lockerbie, and Jason Seitz

Heading into the 2002 elections, Georgia was the only state that had not elected a Republican governor, and the state legislature continued to be held by Democrats. Organizationally, on the other hand, both parties had made dramatic strides since the 1970s, when they had a minimal presence at the local level. The decade of the 1990s brought diverging trends to the two parties. The county chairs we surveyed in 2001 tended to be more active in performing campaign activities than respondents from ten years before. Republican chairs overwhelmingly thought their organizations were getting stronger, though, while Democrats were more pessimistic about their parties. The parties became more ideologically extreme between 1991 and 2001. It remains to be seen whether the Republican trend in grassroots activity will translate into electoral success.

\title{
Introduction
}

For many years, Georgia was a staunch member of the Democratic "solid South" in its voting patterns. The Republican Party never so much as nominated a candidate for governor between the end of Reconstruction in 1876 and 1962. At the dawn of the 21st century, however, the two parties seem evenly matched in terms of their support in the electorate and the development of their party organizations. The current parity is more of a delicate balance than a stable equilibrium, though, as what once appeared to be a Republican takeover has stalled out for the time being. Whether the state's Democrats are able to maintain their present status depends in large measure on their ability to hold together their multiracial coalition.

\section{Development of Political Parties in Georgia}

The growth of the Republican Party-and the corresponding decline in Democratic dominance - has been gradual and marked by frequent reversals of fortune. Republican gains in electoral politics have come at the expense of Democratic victories. The development of GOP party organizations, in contrast, has spurred corresponding Democratic growth.

JOHN A. CLARK is an associate professor of political science at Western Michigan University. AUDREY A. HAYNES is an assistant professor of political science at the University of Georgia, BRAD LOCKERBIE is an associate professor of political science at the University of Georgia., and JASON SEITZ is a Ph.D. student at the University of Georgia.

The American Review of Politics, Vol. 24, Spring, 2003: 35-52

(C)2003 The American Review of Politics 
Table 1. Republican Strength in Georgia, 1960-2000

\begin{tabular}{|c|c|c|c|c|c|c|}
\hline Year & $\begin{array}{c}\text { Percent of } \\
\text { Presidential } \\
\text { Vote }\end{array}$ & $\begin{array}{c}\text { Percent of } \\
\text { Gubernatorial } \\
\text { Vote }\end{array}$ & $\begin{array}{c}\text { Percent of } \\
\text { U.S. Senate } \\
\text { Vote }\end{array}$ & $\begin{array}{l}\text { Percent of } \\
\text { U.S. House } \\
\text { Delegation }\end{array}$ & $\begin{array}{l}\text { Percent of } \\
\text { State House } \\
\text { Delegation }\end{array}$ & $\begin{array}{r}\text { Percent of } \\
\text { State Senate } \\
\text { Delegation }\end{array}$ \\
\hline 1960 & 37.4 & & 0.0 & 0.0 & 1.0 & 1.8 \\
\hline 1962 & & 0.0 & 0.0 & 0.0 & 1.0 & 3.7 \\
\hline 1964 & 54.1 & & & 10.0 & 2.0 & 16.7 \\
\hline 1966 & & 46.5 & 0.0 & 20.0 & 10.7 & 13.0 \\
\hline 1968 & $30.4^{*}$ & & 22.5 & 20.0 & 13.3 & 12.5 \\
\hline 1970 & & 40.6 & & 20.0 & 13.8 & 12.5 \\
\hline 1972 & 75.0 & & 46.0 & 10.0 & 10.8 & 10.7 \\
\hline 1974 & & 30.9 & 28.2 & 0.0 & 15.0 & 14.3 \\
\hline 1976 & 33.0 & & & 0.0 & 13.9 & 8.9 \\
\hline 1978 & & 19.3 & 16.9 & 10.0 & 13.3 & 7.1 \\
\hline 1980 & $41.0^{*}$ & & 50.9 & 10.0 & 11.1 & 8.9 \\
\hline 1982 & & 37.2 & & 10.0 & 12.8 & 8.9 \\
\hline 1984 & 60.2 & & 20.1 & 20.0 & 13.3 & 12.5 \\
\hline 1986 & & 29.5 & 49.1 & 20.0 & 14.4 & 16.1 \\
\hline 1988 & 59.8 & & & 10.0 & 15.0 & 17.9 \\
\hline 1990 & & 44.5 & 0.0 & 10.0 & 20.0 & 19.6 \\
\hline 1992 & $42.9 *$ & & $50.6^{* *}$ & 36.4 & 28.9 & 26.8 \\
\hline 1994 & & 49.0 & & $54.5^{* * *}$ & 37.2 & 39.3 \\
\hline 1996 & 47.0 & & 47.5 & 72.7 & 43.9 & 39.3 \\
\hline 1998 & & 44.0 & 52.4 & 72.7 & 43.3 & 39.3 \\
\hline 2000 & 54.7 & & 39.0 & 72.7 & 41.7 & 44.6 \\
\hline \multicolumn{7}{|c|}{$\begin{array}{l}\text { Notes: *American Independent candidate George C. Wallace won with } 42.8 \text { percent in } 1968 \text { to } \\
\text { Republican Richard M. Nixon's } 30.4 \text { and Democrat Hubert H. Humphrey's } 28.8 \text {; Democrat Jimmy } \\
\text { Carter won with } 56.7 \text { percent in } 1980 \text { to Ronald Reagan's } 41.0 \text { and Independent John B. Anderson's } \\
\text { 2.3; Democrat Bill Clinton won with } 43.5 \text { percent in } 1992 \text { to Republican George Bush's } 42.8 \text { and } \\
\text { Independent H. Ross Perot's 13.3. **Republican vote percentage in the runoff election. ***Nathan } \\
\text { Deal (9th District) won reelection as a Democrat but switched to the Republican party. } \\
\text { Sources: Compiled from America Votes (Washington, DC: Congressional Quarterly, 1956-1992), } \\
\text { Volumes 1-20, and Members of the General Assembly of Georgia Senate and House of Represen- } \\
\text { tatives (Atlanta: State of Georgia, 1954-1992). }\end{array}$} \\
\hline
\end{tabular}

\section{Electoral Patterns}

The trend of Republican electoral victories provides evidence for splitlevel realignment, with early successes at the presidential level filtering down to lower-level offices (Bullock 1988; Aistrup 1996). The party made its first inroads in support of Dwight Eisenhower in the 1950s, as the Republican nominee was able to win a third of the popular vote in his two presidential campaigns. When John Kennedy captured Georgia's electoral votes in 1960 (see Table 1), it marked the last time a nonsouthern Democrat did 
so. Jimmy Carter, who was elected governor in 1970, carried his home state in 1976 and 1980, interrupting a string of Republican landslides in 1972, 1984, and 1988. The contests of the 1990s were decided by the narrowest of margins: Democrat Bill Clinton beat the incumbent George Bush by a margin of less than one percentage point in 1992, then lost to Bob Dole in 1996 by a similar margin. George $\mathrm{W}$. Bush won a more comfortable victory over Al Gore in 2000 with almost 55 percent of the vote (Bullock 2002).

Prior to the 2002 elections, Georgia remained the only state that had not elected a Republican governor since Reconstruction. Republican Howard "Bo" Calloway won a plurality of votes in 1966, but the election was decided by the Democratically-controlled General Assembly because no candidate won a majority of votes (Bass and DeVries 1976, 141-144). The elections of the 1990s featured strong GOP challenges to Democratic dominance. In 1994, GOP nominee Guy Millner came within 33,000 votes of unseating incumbent Zell Miller. Republican gubernatorial candidates averaged almost 46 percent of the vote from 1990 to 1998 without ever reaching a majority.

Statewide elections for U.S. Senate have been close as well. Only former Senator Sam Nunn, a Democrat who served from 1973 to 1996, seemed immune from challenge after first winning his seat with only 54 percent of the vote. All five Senate elections between 1980 and 1998 in which Nunn was not a candidate were decided by narrow margins.

The greatest Republican successes have come in congressional elections. In 1990, the only Republican member of the United States House delegation was Newt Gingrich, who was first elected in 1978. By 1995, eight of the eleven seats were held by Republicans. Much of the Republican success resulted from the redistricting process following the 1990 census. The Bush Administration Justice Department vetoed the district map drawn by the General Assembly. A coalition of Republicans and black Democrats pushed a plan that created three majority-black districts. African American Democrats won those seats, but the remaining seats, bleached of core Democratic voters, were controlled by white Republicans by 1995 . The U.S. Supreme Court eventually threw out the racially gerrymandered plan, but the damage to moderate white Democrats' electoral chances had already been done (Bullock 1998).

Democrats continue to control the General Assembly. Here, too, Republicans are mounting a strong challenge to Democratic hegemony. The increase in GOP seats has been fairly consistent over the last three decades. Many of these legislative successes are located in the Atlanta metropolitan area, one of the fastest growing regions of the country. Republican candidates have been aided by the state party's ORVIS program (Optimal Republican Voting Strength) that allowed them to target Republican-leaning 
districts (Bullock and Shafer 1997). Had Republican candidates picked up a few thousand more votes in key districts, they would have won a narrow majority of seats in the state senate in 2000 (Bullock 2002, 75).

\section{Organizational Development}

Party organizations were slow to develop in Georgia. A "one-party" state in electoral politics, the Democratic dominance did not translate into strong organizations. In fact, organizational weakness was preferred so that no candidate or faction would gain an advantage in the all-important Democratic primary (Key 1949). When it became apparent that Barry Goldwater would have considerable support in the 1964 presidential election, the state Democrats created their first state headquarters and hired an executive director. County party organizations had functioned as election boards up to that point and were ill-prepared to take on campaigning in the general election (Clark 1997). Goldwater's victory set the stage for subsequent GOP successes in presidential politics, but a lack of competition in local elections slowed the development of Democratic Party organizations at that level.

Republican attempts to develop a strong organizational infrastructure were frustrated by a lack of electoral success throughout the 1960s and 1970s. Every time a winning candidate appeared to give the party some momentum, a significant setback seemed to stop things in their tracks (Clark 1997). Party leaders focused their attention on raising funds and recruiting candidates. The long range strategy eventually paid off, but local Republican organizations were rated as the weakest in any state for either party as of the late 1970s (Cotter et al. 1984, 53). ${ }^{1}$

Both state parties grew substantially over the decade of the $1980 \mathrm{~s}$. An influx of money from the national parties, especially the Republican National Committee, was dedicated to organizational development. State Republicans used these resources to establish a "top-down" development strategy, doling out resources to county organizations that followed the state party's plan. Other resources were devoted to the recruitment, training and support of candidates who ran as Republicans. As their likelihood of electoral success increased, more self-starters were willing to register their candidacies as Republicans. At the same time, the highly successful ORVIS program allowed state leaders to allocate their resources in a way that maximized electoral victories (Bullock and Shafer 1997). Georgia's Democrats generally have been less willing to interfere with county party autonomy, instead emphasizing communication over compliance. The state party recruits candidates for statewide and state legislative (but not local) offices (Clark 1997).

The different processes by which the current state party chairs were selected seem to run counter to the organizational development strategies 
that the parties employ. In both parties, the chair officially is elected by the state convention. In practice, the Democratic chair is selected by the party's gubernatorial nominee, in keeping with the Democrats' continuing success at winning this office. The selection of the chair can reflect personal ties to the nominee or serve as an effort to bridge divisions within the party (or both). The current chair, Calvin Smyre, is a long-serving and well-respected state representative. As chair of the House Rules Committee, he is also the highest-ranking African American in the legislature (Baxter 2001).

The biennial selection of state Republican chair is often marked by factional strife as candidates from different wings of the party vie for control. The current chair, Ralph Reed, is a political consultant who rose to national prominence as executive director of the Christian Coalition in the 1990s. Reed defeated two other candidates for the position (Pruitt 2001). His predecessor also beat two other candidates, and the chair before that first won on the fourth ballot in 1995 (Pruitt 1999; Baxter 1995). Reed's selection should not be viewed as evidence of social conservative dominance of the state party, though. His success as a fundraiser was widely cited at the time of his selection. He is credited with doubling the party's individual donor base in his first year in the position (Galloway 2002).

\section{Grassroots Party Activists, 2001 and 1991}

Given the changes that have transpired in Georgia's electoral politics, we have every reason to expect that similar changes have taken place among the state's party activists. Comparison of county chairs ${ }^{2}$ in 2001 to those surveyed in 1991 reveal considerable stability combined with evidence of ideological polarization and organizational vitality.

\section{Social and Demographic Characteristics}

County chairs in Georgia are elite both politically (by nature of their position in the party) and socially. They are overwhelmingly white, male, and well-off financially (see Table 2). Nearly all of the chairs we surveyed are white. Interestingly, there are more female chairs in the GOP (28 percent) than in the Democratic party (12 percent). This figure represents a substantial change among Republicans; in 1991, only 11 percent of county chairs were women. Only 3 percent of the chairs in both parties earn less than $\$ 25,000$, while roughly half have incomes greater than $\$ 75,000$. About one in ten earn incomes in excess of $\$ 150,000$. In a state where the median household income is $\$ 41,000$, our chairs are clearly representative of a higher income bracket. The chairs are well-educated, too. Sixty-one percent of Democrats and 67 percent of Republicans earned at least a college degree. ${ }^{3}$ 
40 | John A. Clark, Audrey A. Haynes, Brad Lockerbie, and Jason Seitz

Table 2. Demographic Profiles of Georgia Party Activists, County Chairs Only

\begin{tabular}{|c|c|c|}
\hline & Democrats & Republicans \\
\hline Gender: \% males & 88 & 72 \\
\hline Race: \% white & 97 & 98 \\
\hline Income: $\% \$ 75,000+$ & 49 & 51 \\
\hline Education: \% college degree & 61 & 67 \\
\hline $\begin{array}{l}\text { Religion: } \% \text { mainline Protestant } \\
\text { \% evangelical Protestant } \\
\% \text { black Protestant } \\
\% \text { Catholic } \\
\% \text { other or none }\end{array}$ & $\begin{array}{r}46 \\
36 \\
3 \\
13 \\
2\end{array}$ & $\begin{array}{r}49 \\
44 \\
1 \\
5 \\
2\end{array}$ \\
\hline Church attendance: $\%$ weekly or almost weekly & 75 & 64 \\
\hline Importance of religion: \% great deal & 47 & 67 \\
\hline Born-again Christian: \% yes & 56 & 65 \\
\hline Christian right: $\%$ feeling close & 18 & 50 \\
\hline $\begin{array}{ll}\text { Age: } & \% \text { over } 50 \\
& \% \text { over } 65\end{array}$ & $\begin{array}{l}73 \\
48\end{array}$ & $\begin{array}{l}66 \\
33\end{array}$ \\
\hline $\begin{array}{ll}\text { Years lived in state: } & 10 \text { or less } \\
25 \text { or less }\end{array}$ & $\begin{array}{r}4 \\
13\end{array}$ & $\begin{array}{l}10 \\
30\end{array}$ \\
\hline $\begin{array}{l}\text { Regional background: \% from North } \\
\text { (N) }\end{array}$ & $\begin{array}{c}15 \\
(69)\end{array}$ & $\begin{array}{r}24 \\
(115)\end{array}$ \\
\hline
\end{tabular}

One potential problem faced by both parties is the aging of this group of activists. In 1991, only about a third of the chairs in our survey were more than 50 years old. In 2001, nearly three-fourths of Democrats and two-thirds of Republicans fit in this category. Nearly half of the Democratic chairs and a third of the Republican chairs were more than 65 years old in the most recent survey. Maintaining the vitality of the party requires that a continuous stream of new activists be recruited. A developed organization allows an activist to gain experience within the party before rising to a position of authority; an aging organization lacks the ability to recruit new members into the party. Our data do not allow us to determine which of these scenarios is most common in the state, but the trend is worth watching into the future, especially for Democrats. 
Migrants to the state continue to provide a larger base for the Republican party, but the difference between parties is shrinking due mostly to changes in the Democratic party. Four out of five Democratic chairs in 2001 were raised in Georgia, down from 95 percent in 1991. Sixty percent of the Republican chairs in 2001 were native Georgians compared to 52 percent in 1991. Fifteen percent of Democrats were raised outside the South (up from only 2 percent in 1991), as were 24 percent of Republicans (down from 29 percent). Thirty percent of the Republicans in our survey moved to Georgia within the last 25 years, compared to 13 percent of the Democrats.

The religious differences between Republicans and Democrats are relatively minor. Nearly all come from Protestant denominations. Three-fourths of Democratic chairs and almost two-thirds of Republican chairs attend church weekly or almost weekly. Republicans are more likely to indicate that religion is provides a "great deal" of guidance in their daily lives. They are slightly more likely to indicate that they are born again, too. Half of the Republican chairs indicate that they feel close or very close to "Christian Right" organizations, compared to only 18 percent of the Democrats.

\section{Recruitment to Office}

People choose to become active in politics for a variety of reasons. Among county chairs in Georgia, not much has changed over the last decade. For the most part, those active in party affairs are self-starters. When asked what played a role in their decision to seek their current position, half of the chairs in both parties said that the decision was pretty much their own. The respondents answered much the same when queried about their involvement in politics in general. There are, however, some partisan differences that we should note. Democrats are modestly more likely to report that they were recruited to their current position by a party official than are Republicans. The impetus to get involved in politics at all shows this distinction much more strongly. Here, Democrats are approximately four times as likely as Republicans to report that a party official recruited them (41 percent versus 11 percent). Democrats are also approximately three times as likely to report recruitment by an elected official ( 31 percent versus 10 percent).

Clark and Wilson (1961) identified three types of incentives or benefits that motivate people to become active in organizations. Chairs in both parties identify purposive incentives as more important than material or solidary incentives. Both Democrats and Republicans overwhelmingly (two-thirds or more) identified a concern with public issues and to support a candidate they believed in as very important considerations. Democrats (28 percent) are more likely than are Republicans (11 percent) to identify family involvement in politics (a solidary incentive) as a personal reason for seeking their 
current position. Very few chairs indicated they pursued their position for material gain.

\section{Patterns of Activity}

One of the ways in which political scientists have examined political parties is through their activities (see, for example, Feigert and Todd 1998; Clark, Lockerbie, and Wielhouwer 1998). The types of activities they perform as well as the level to which they carry them out serve as indicators of the goals of the party as well as the vitality of the party. In this section we will discuss the types of activities the county chairs in Georgia believed were important as well as the degree to which they have engaged in them.

We asked county chairs which types of activities are among the important things that they do in their capacity as a member of their county party organization. The results of the survey closely mirror those from 1991. County chairs in Georgia, regardless of party, are well attuned to the need to carry out a host of activities. There were no significant differences between the parties on the importance of thirteen of the fourteen areas of party activity. ${ }^{4}$ The only exception was the response to policy formation. Forty-three percent of Republican chairs reported that policy formation was a very important activity for them, compared to only 25 percent of Democrats. Overall, chairs in both parties thought our list represented quite important tasks. Party leaders ranked policy formation, nominating activities, and helping to develop a party website lower than others in terms of salience to their job.

The goal of a political party is to win elected office. Thus, campaign activities are presumed to be among the most important activities a party can carry out. We asked county chairs which activities they engaged in during the recent election campaigns. Again, most chairs took part in at least some of these activities. Contributing money, distributing posters or signs, organizing events and distributing campaign literature were the most frequently performed activities (see Table 3). In most cases, chairs of both parties were generally active at similar levels. Those areas diverging somewhat were creating and maintaining a website, sending mailings to voters, and distributing posters or signs (more Republican activities), conducting voter registration drives, and dealing with the media (more Democratic activities). Overall, Republican chairs were slightly more active than Democrats, but the difference between parties is small.

Table 3 also includes the activity levels from our 1991 survey. For every activity, the percentage of chairs who reported performing it increased or remained constant across the decade of the 1990s with but one exception. Republican chairs were slightly less likely to report using public opinion 
Table 3. Campaign Activities of Georgia Party Activists, County Chairs Only

\begin{tabular}{|c|c|c|c|c|}
\hline & \multicolumn{2}{|c|}{ Democrats } & \multicolumn{2}{|c|}{ Republicans } \\
\hline & 1991 & 2001 & 1991 & 2001 \\
\hline Organized canvassing efforts & 20 & 38 & 32 & 42 \\
\hline Organized campaign events & 66 & 78 & 66 & 73 \\
\hline Organized fund-raising activities & 56 & 58 & 59 & 64 \\
\hline Sent mailings to voters & 33 & 44 & 51 & 62 \\
\hline Distributed campaign literature & 71 & 78 & 72 & 81 \\
\hline Organized telephone campaigns & 36 & 51 & 44 & 49 \\
\hline Distributed campaign posters, signs & 67 & 80 & 81 & 93 \\
\hline Contributed money & 84 & 84 & 85 & 89 \\
\hline Conducted voter registration drives & 28 & 44 & 23 & 30 \\
\hline Utilized public opinion surveys & 13 & 14 & 21 & 17 \\
\hline Dealt with media & 56 & 63 & 57 & 57 \\
\hline Helped with campaign websites & - & 8 & - & 17 \\
\hline$(\mathrm{N})$ & (61) & (73) & (53) & (120) \\
\hline \multicolumn{5}{|c|}{$\begin{array}{l}\text { Note: Entries are the percent who said that they engaged in the campaign activity in recent elections. } \\
\text { The minimum number of respondents from each party and position is in parentheses. } \\
\text { Source: Southern Grassroots Party Activists } 1991 \text { and } 2001 \text { data, Georgia sample. }\end{array}$} \\
\hline
\end{tabular}

surveys ( 21 percent to 17 percent), a difference that is not substantively meaningful. If activity performance by their chairs is any indicator, county parties in Georgia were stronger in 2001 than they were a decade earlier.

We also asked our chairs if they worked as actively in elections at one level as they do in elections at other levels. In general, both parties had similar degrees of involvement at each campaign level. Both were highly active in local and state campaigns. Republican activity in local elections was up considerably from 1991. In that year, 81 percent reported being somewhat or very active in local elections, compared to 95 percent in 2001. This change reflects the spread of GOP activity into local elections in all parts of the state. As in 1991, the reported activity in national elections was significantly different across parties. In our 2001 sample, 70 percent of Democratic respondents reported being somewhat or very active in national elections (up from 63 percent) while close to 92 percent of the Republican respondents claimed the same level of activity (up from 89 percent).

Taken together, these results suggest that the role played by local party organizations in election campaigns became more important across the decade of the 1990s. Chairs in both parties were quite active in 1991; they are even more active today. Political party organizations may no longer be the central vehicles for conducting campaigns, but they remain important in their support of candidates. 


\section{Political, Social, and Economic Attitudes}

Until recently, political parties in the South appeared less polarized than those in the rest of the country. As conservatives left their Democratic roots and, in some instances, liberal Republicans found a new home, the differences between the two parties grew increasingly stark. ${ }^{5}$ Table 4 displays the increasing polarization found in our sample of our county chairs. In 1991, a larger percentage of Democratic chairs considered themselves to be somewhat or very conservative (53 percent) than somewhat or very liberal (20 percent). Those proportions were largely reversed a decade later (22 percent conservative to 39 percent liberal). Republicans, already conservative in 1991, became more extreme by 2001 as the share of those who identified themselves as "very conservative" increased from over half to nearly twothirds.

The same pattern is present on specific public policies. There is considerable variation across policy items, yet substantial partisan differences can be found across economic, civil rights, and social issues (see Table 5). Two issues in each category show differences of at least 50 percentage points across parties. On only one of the issue items, whether women should play an equal role in government and business, does the difference between the two parties fail to reach statistical significance. ${ }^{6}$

An examination of economic issues shows that Democrats are more supportive of an activist government than Republicans. The largest difference on any of the issue items comes from whether government should reduce services to cut spending. Ninety-one percent of Republican chairs favored smaller government, while 86 percent of the Democrats took the opposite view. Substantial majorities from each party also differed on government regulation of the health care system. Democratic support for activist government was not universal, however. Two-thirds opposed a government-guaranteed job and standard of living, a position shared by nearly all Republicans. Republican chairs were overwhelmingly supportive of a flat tax system, while Democratic chairs were evenly split on the issue.

Issues of civil rights and equality display similar patterns of divergence and convergence. As noted above, there is no meaningful difference between Republicans and Democrats on women's equality. Likewise, 85 percent of Democrats and all of the GOP chairs oppose hiring preferences for blacks. At the same time, there was a considerable split between the parties on whether the national government should work "to improve the social and economic situation" of women and blacks or other minority groups. More than three-fourths of Democratic chairs agreed with those statements, while less than a quarter of Republicans took the same positions. A majority of Democrats favor laws that would protect gay and lesbian workers from discrimination, a view shared by only 16 percent of Republican chairs. 
Table 4. Ideological Orientation of Georgia Party Activists, County Chairs Only

\begin{tabular}{lcccc}
\hline & \multicolumn{3}{c}{ Democrats } & \multicolumn{2}{c}{ Republicans } \\
Ideological Orientation & 1991 & 2001 & 1991 & 2001 \\
\hline Very liberal & 2 & 7 & 0 & 0 \\
Somewhat liberal & 18 & 32 & 0 & 0 \\
Moderate & 28 & 38 & 4 & 4 \\
Somewhat conservative & 48 & 18 & 49 & 31 \\
Very conservative & $\frac{5}{100 \%}$ & $\frac{4}{100 \%}$ & $\frac{47}{100 \%}$ & $\frac{65}{100 \%}$ \\
& $(61)$ & $(71)$ & $(53)$ & $(118)$ \\
(N) & \multicolumn{3}{l}{ Note: Entries are percentages. The number of respondents from each party is in parenthesis. }
\end{tabular}

Table 5. Issue Orientation of Georgia Party Activists, County Chairs Only

\begin{tabular}{lcc}
\hline Issue & Democrats & Republicans \\
\hline Economic Issues & & \\
$\quad$ Government services, spending & 14 & 91 \\
Guaranteed job and living standard & 68 & 97 \\
Regulation of health care & 28 & 85 \\
$\quad$ Flat tax system & 49 & \\
Civil Rights and Equality Issues & & 77 \\
Improve minorities' situation & 24 & 100 \\
Hiring preferences for minorities & 85 & 13 \\
Equal role for women & 3 & 77 \\
Improve women's situation & 22 & 84 \\
Gay job discrimination & 42 & 65 \\
Social Issues & & 90 \\
Abortion & 23 & 93 \\
Death penalty & 61 & 73 \\
School prayer & 63 & 96 \\
School vouchers & 19 & $(114)$ \\
Handgun control & 35 & \\
(N) & $(66)$ & \\
Note: Entries are the percentages of respondents who took a conservative position (agree/strongly \\
agree or disagree/strongly disagree) with each issue statement. The minimum number of respondents \\
from each party is in parentheses. & & \\
\hline
\end{tabular}


The largest differences on social issues involved school vouchers and gun control, two hot-button issues of national importance. Majorities of both parties support the death penalty and prayer in school, although Republican support is considerably stronger. More than three-fourths of the Democratic chairs think that abortion should be a matter of personal choice, while approximately one-third of Republican activists agree with this position.

Eight of the same policy questions were asked in identical form in 1991. Significant polarization (defined as increased polarization of ten points or more) occurred on half of the eight issues: government services, aid to minorities and to women, and hiring preferences for minorities. All four of those issues were widely discussed across the decade. For three of the four issues, the polarization resulted largely from Democratic chairs adopting increasingly liberal positions. Republican chairs grew dramatically more conservative on the government's efforts to aid women. Smaller changes were found on women's equality, a government guaranteed job, abortion, and school prayer.

We also asked our respondents in 2001 a series of questions about government spending. As with the policy issues, Democrats consistently took more liberal positions than Republicans. For Democrats, majorities supported increased spending on health care, education, and social security. Almost half supported increases in spending on the environment and crime prevention. The only area for which a majority of GOP chairs supported increased spending was defense. A large majority of Republicans favored cutting welfare programs, and a substantial plurality (45 percent) favored less federal spending on education.

In order to better understand the differences within and between parties on these spending issues, we calculated difference scores for each party by subtracting the percentage of county chairs who would reduce spending from the percentage who would increase spending (the others prefer the status quo). Positive scores indicate an overall preference for increased spending, negative scores for decreased spending. The difference scores are displayed in Table 6. With the exception of defense, Democratic chairs are considerably more supportive of increased spending than their Republican counterparts.

\section{Changes in Party Strength}

Party organizations are important institutions for assembling resources and mobilizing voters in pursuit of political goals. There is often variation in terms of organizational strength and vitality across local partisan units. Some are quite strong while others are barely active. Yet the degree of organizational strength has been shown to influence a host of factors that are associated with the success of the party within its geographic area (Frendreis, 
Table 6. Orientation on Spending Issues for Georgia Party Activists, County Chairs Only

\begin{tabular}{lccc}
\hline Spending Item & Democrats & Republicans & Difference \\
\hline Defense & 27 & 80 & 53 \\
Environment & 47 & -33 & -80 \\
Schools & 67 & -27 & -94 \\
Crime & 40 & 9 & -30 \\
Social Security & 69 & 8 & -65 \\
Health care & 69 & -26 & -95 \\
Welfare programs & -14 & -86 & -72 \\
(N) & $(70)$ & $(118)$ &
\end{tabular}

Note: Entries in the first two columns are the percentage favoring increased spending minus the percentage favoring decreased spending. The entries in the third column are the Republican score minus the Democratic score. The minimum number of respondents from each party is in parentheses.

Gibson, and Vertz 1990; Coleman 1996). When we examine perceived changes in party organizational strength in Georgia, we find significant variation across parties. Democratic chairs are more pessimistic about their status, obviously concerned about a decline in their party's strength. Republicans, on the other hand, clearly see improvement both within the state as a whole and within their own counties.

When chairs were asked to describe their county party organization's overall level of strength, the differences across parties were significant. Only 14 percent of the Democratic chairs believed their county party organization to be significantly stronger than it had been 10 years earlier. More than a third of Democrats selected the categories of somewhat or significantly weaker. In contrast, nearly 6 in 10 Republicans thought that their county organization was stronger while only 3 percent felt their organization had declined in strength. Thus, Republican and Democratic chairs have very divergent views of the directions their local organizations are heading.

A similar pattern persists across a host of specific organizational attributes. For example, when asked about the change in their party's campaign effectiveness from the prior decade, many Democrats felt there had been some positive change (40 percent). However, most Democratic chairs believed there had been no change ( 30 percent) or their campaign effectiveness had actually decreased (30 percent). Again, Republicans' responses were significantly different. Close to 84 percent of those surveyed believed their local organization's campaign effectiveness had increased whereas only 9 percent saw no change and 3 percent saw a decrease in campaign effectiveness. The pattern repeats itself for the county party organization's ability to 
raise funds, recruit candidates, develop organization skills of party workers, and use media and polls effectively. In each of these cases, while there were some Democratic chairs who saw increases in these areas, the majority reported no change or a weakening for their party. The opposite case emerged for the Republican organizations. In every instance substantial majorities responded positively, with fewer than 5 percent reporting a weakening in any of these areas. The Democrats were most optimistic about their use of computer technology, with close to 57 percent of the Democratic chairs reporting increased strength in this area. However, the Republican chairs boast 83 percent of county party organizations being stronger in their computer technology use.

The final area of change tells much about the decline of Democratic electoral fortunes. When asked about their party's strength among county voters, nine out of ten Republican chairs stated that their party-in-theelectorate was stronger than it was a decade earlier, while only 3 percent reported weakening of support. Almost 40 percent of the Democratic respondents reported being stronger in their county voter support, 27 percent reported no change, and more than a third reported a weakening of support. In sum, all of the indicators of party organizational strength point to the perception among most chairs that the Democrats have experienced little change or a weakening of their organizational capacity while the Republicans have increased theirs over the last decade.

\section{Factionalism in Georgia Parties}

When organizations exhibit dissension among the ranks, their ability to achieve their goals is hampered. Thus, maintaining unity is an important goal for party leaders. A large, diverse organization is more likely to splinter into a variety of factions. Homogeneity, whether in demographic characteristics or attitudes, is likely to reduce factional tensions.

Factional divisions have a long history within the Democratic party in Georgia. V.O. Key (1949) identified the Talmadge and more progressive anti-Talmadge factions as structuring voting patterns in the one-party Democratic primaries. More recent splits have centered around traditional, conservative Democratic loyalists and more liberal (and often African American) activists. In the GOP, the split between social conservatives and socalled "country club Republicans" has divided the party since the Eisenhower administration (Clark 1997).

When asked to assess the degree of factionalism within the state party, Democratic and Republican chairs expressed similar views. Roughly half of Democrats and slightly fewer Republicans thought there was high to moderate factionalism within the state party. Significant differences emerge 
when asked about their county parties, however. Among Democrats, 28 percent of chairs reported moderate to high factionalism, compared to only 14 percent of GOP chairs.

We asked our chairs what caused the factionalism in their state party. In both parties, the most frequent cause of factionalism was disagreement between urban and rural areas of the state. More than three-fourths of Democrats and almost seven in ten Republicans indicated at least a fair amount of factionalism based on this division, which dates back to the Talmadge era. In

addition, 65 percent of Democrats and 56 percent of Republicans reported regional splits; in Georgia, the two things are similar with the Atlanta metropolitan area conflicting with the rest of the state. Other important causes of factionalism in both parties include ideological splits, abortion, and disagreement between party leaders.

In the aggregate, nearly half of Democratic chairs rated each of the nine possible causes as contributing a fair amount or more to factional splits. The two parties differed significantly on four of the items: new and old residents, taxes, racial issues, and government spending.

In sum, the two parties are equally likely to see factionalism present in their state parties, with Democrats acknowledging more tension in their county parties. Democrats attribute their state factionalism to a wider variety of causes. We suggest two possible interpretations for these results. First, the higher levels of factionalism could result from the Democratic party's longstanding majority status. Majority parties generally house a greater variety of issue preferences among leaders and activists given the large size of the party membership. From this perspective, greater factionalism is simply the fruit of Democratic success in Georgia politics. Alternatively, as the descendent party within the state, Democrats may be finding themselves at odds with one another over a variety of possible explanations for their electoral decline. In other words, the factionalism that is present might be nothing more than finger-pointing by frustrated activists.

\section{Conclusion}

A decade ago, it appeared that two-party competition had finally arrived in Georgia (Lockerbie and Clark 1995). The question now is whether Republican growth and Democratic decline will stop once parity is reached or whether the two parties will continue on their disparate paths of electoral success. The evidence we examine here leads to competing conclusions.

In terms of electoral success, the decade of the 1990s saw Republican gains in statewide elections stall out. Neither party was able to dominate contests for President, governor, the U.S. Senate, or even lower statewide offices. Below the state level, the GOP increased its strength. Republicans 
captured a majority of the seats in the U.S. House and came closer to parity in both chambers of the General Assembly. Competition for local office extended to parts of the state where the GOP once feared to tread.

In terms of party organizations, some evidence from our survey of county chairs indicates that the Republicans are on the brink of asserting themselves as the dominant party. Republican chairs overwhelmingly see their party organizations as gaining strength, while Democratic chairs perceive more mixed trends. Democrats must also face the challenge of replacing an aging cohort of party leaders. Unless new activists are recruited into their organizations, they risk dire consequences in the future. On the other hand, chairs of both parties report increasing levels of campaign activity compared to those we surveyed in 1991. Higher activity levels are hardly what one would expect from organizations in decline. Levels of perceived factionalism in the state parties are roughly equal, too, which suggests that internal divisions are no worse for Democrats than for Republicans.

In sum, these trends bear watching into the next decade and beyond. Absent organizational development by state GOP leaders, it is unlikely that the party's electoral successes across the latter half of the 20th century would have been so great. The Democratic response in organizational infrastructure may provide the barrier the party's candidates need to keep Republicans in check.

\section{NOTES}

\footnotetext{
${ }^{1}$ Democratic county organizations did not fare much better. Cotter and his colleagues ranked them 46th among Democrats and 93rd overall. Both state parties were rated Amoderately strong," with the GOP holding a substantial advantage within that broad category (Cotter et al. 1984, 28-29, 52-53).

${ }^{2}$ Unlike the other chapters of this volume, we only analyze county chairs rather than lower-level activists. Due to a lack of cooperation by the state parties, we have no way of knowing whether the small number of precinct members we surveyed are representative of the population of those activists. With 73 Democratic and 120 Republican county chairs drawn from Georgia's 159 counties, we have a substantial number of cases for making comparisons. Our previous analysis of the 1991 data used both chairs and precinct members (Lockerbie and Clark 1995).

${ }^{3}$ These education levels are down slightly from 1991, when 67 percent of Democratic chairs and 76 percent of Republican chairs had graduated from college. While we can only speculate as to why (and whether the differences are substantively meaningful), one possibility is that a larger percentage of rural counties is represented in our sample this time. For Republicans, this might indicate the spread of the party into areas that were the last holdouts of one-party Democratic strength.

${ }^{4}$ These items include contacting voters, raising money, getting people to register to vote, campaigning, public relations, county organizational work, participating in party meetings and business, recruiting and organizing workers, increasing political informa-
} 
tion for others, contacting new voters, getting candidates for local office, other nominating activities and helping to develop a party website.

${ }^{5}$ For evidence of party sorting among activists of different levels, see Clark et al. (1991) and Prysby (1998).

${ }^{6} \mathrm{We}$ calculated Tau-c coefficients for each of the items using the full distribution (from strongly agree to strongly disagree). All the Tau-c scores were statistically significant at $p<.001$ except for the women's equality item $(p=.378)$.

\section{REFERENCES}

Aistrup, Joseph A. 1996. The Southern Strategy Revisited: Republican Top-down Advancement in the South. Lexington: University Press of Kentucky.

Bass, Jack, and Walter DeVries. 1976. The Transformation of Southern Politics. New York: Basic Books.

Baxter, Tom. 1995. New Leader Shows GOP Growing Up in Georgia. Atlanta Constitution, May 16.

Baxter, Tom. 2001. New Party Chief Has Stellar Resumé. Atlanta Constitution, October 4.

Bullock, Charles S. III. 1988. Creeping Realignment in the South. In The South's New Politics: Realignment and Dealignment, eds. Robert H. Swansbrough and David M. Brodsky. Columbia: University of South Carolina Press.

Bullock, Charles S. III. 1998. Georgia: Election Rules and Partisan Conflict. In The New Politics of the Old South, eds. Charles S. Bullock III and Mark J. Rozell. Lanham, MD: Rowman \& Littlefield.

Bullock, Charles S. III. 2002. Georgia: Another Mixed Partisan Result. In The 2000 Presidential Election in the South, eds. Robert P. Steed and Laurence W. Moreland. Westport, CT: Praeger.

Bullock, Charles S. III, and David J. Shaffer. 1997. Party Targeting and Electoral Success. Legislative Studies Quarterly 22:573-584.

Clark, John A. 1997. Georgia. In State Party Profiles: A 50-State Guide to Development, Organization, and Resources, eds. Andrew M. Appleton and Daniel S. Ward. Washington, DC: Congressional Quarterly.

Clark, John A., John M. Bruce, John H. Kessel, and William G. Jacoby. 1991. I'd Rather Switch than Fight: Lifelong Democrats and Converts to Republicanism among Campaign Activists. American Journal of Political Science 35:577-597.

Clark, John A., Brad Lockerbie, and Peter W. Wielhouwer. 1998. Campaign Activities. In Party Organization and Activism in the American South, eds. Robert P. Steed, John A. Clark, Lewis Bowman, and Charles D. Hadley. Tuscaloosa: University of Alabama Press.

Clark, Peter, and James Q. Wilson. 1961. Incentive Systems: A Theory of Organization. Administrative Science Quarterly 6:129-166.

Coleman, John J. 1996. Party Organizational Strength and Public Support for Parties. American Journal of Political Science 40:805-824.

Cotter, Cornelius P., James L. Gibson, John F. Bibby, and Robert J. Huckshorn. 1984. Party Organizations in American Politics. New York: Praeger.

Feigert, Frank B., and John R. Todd. 1998. Party Maintenance Activities. In Party Organization and Activism in the American South, eds. Robert P. Steed, John A. 
52 | John A. Clark, Audrey A. Haynes, Brad Lockerbie, and Jason Seitz

Clark, Lewis Bowman, and Charles D. Hadley. Tuscaloosa: University of Alabama Press.

Frendreis, John P., James L. Gibson, and Laura L. Vertz. 1990. The Electoral Relevance of Local Party Organizations. American Political Science Review 84:225-235.

Galloway, Jim. 2002. State GOP: Reed May Get Struck by Enron Fallout. Atlanta Constitution, February 2.

Lockerbie, Brad, and John A. Clark. 1995. Georgia: Two-Party Political Reality? In Southern State Party Organizations and Activists, eds. Charles D. Hadley and Lewis Bowman. Westport, CT: Praeger.

Key, V.O., Jr. 1949. Southern Politics in State and Nation. New York: Alfred A. Knopf.

Pruitt, Kathey. 1999. State GOP to Pick New Leader. Atlanta Constitution, May 20.

Pruitt, Kathey. 2001. A Decision for Republicans: Is There a Grand Old Party Pooper? Atlanta Constitution, April 30.

Prysby, Charles L. 1998. Party Switchers and the Party System. In Party Activists in Southern Politics: Mirrors and Makers of Change, eds. Charles D. Hadley and Lewis Bowman. Knoxville: University of Tennessee Press. 